\title{
Real-time PCR-based quantification of Toxoplasma gondii in tissue samples of serologically positive outdoor chickens
}

\author{
Cleiton Paulo Aigner ${ }^{1,3}$, Aristeu Vieira da Silva2 ${ }^{2}{ }^{,}$, Fabiano Sandrini ${ }^{3}$, \\ Paulo de Sá Osório ${ }^{3}$, Lilian Poiares ${ }^{3}$, Alvaro Largura ${ }^{3}$ \\ 'Mestrado em Biotecnologia Aplicada à Agricultura, Universidade Paranaense, Umuarama, PR, Brasil \\ ${ }^{2}$ Laboratório de Análises Clínicas e Parasitologia, Departamento de Ciências Biológicas, \\ Universidade Estadual de Feira de Santana, Est. Transnordestina s/n, 44036-900 Feira de Santana, BA, Brasil \\ ${ }^{3}$ Laboratório Álvaro, Centro de Análises e Pesquisas Clínicas, Instituto de Investigação Científica do Paraná, Cascavel, PR, Brasil
}

This study aimed to quantify Toxoplasma gondii in tissue samples of serologically positive chickens using realtime polymerase chain reaction (PCR). Of 65 chickens evaluated, 28 were positive for T. gondii antibodies. Brain and heart samples were collected from 26 seropositive chickens and DNA was extracted using Trizol ${ }^{\circledR}$ and amplified using real-time PCR with SYBR ${ }^{\circledR}$ Green. Parasite DNA was detected in 24 of the 26 samples analyzed; the number of positive tissue samples and the parasite quantity did not differ between tissue types. The results confirmed the analytical sensitivity of parasite detection in chicken tissue samples and demonstrated the possibility of using other molecular systems for genotypic analysis.

Key words: Toxoplasma gondii - chicken - real-time PCR

Toxoplasmosis is a zoonosis that affects millions of people and is caused by the protozoan Toxoplasma gondii (Reischl et al. 2003), an intracellular parasite capable of invading several tissues in mammals and birds (Jauregui et al. 2001).

Domestic chickens (Gallus gallus), mainly those bred in free-range conditions, have been studied all over the world because their feeding habits make them indicators of environmental contamination (Dubey et al. 2006). These birds frequently show high infection rates in all countries studied and common rates of infection range from 39\% (Dubey et al. 2002) to 66\% (Dubey et al. 2006) in Brazil. Most studies of $T$. gondii in chickens use mouse bioassays, but this procedure may take up to two months to complete and the use of animals is an expensive procedure that involves ethical issues. In addition, parasite passage in mice may select for genotypes that are more virulent to this species (Villena et al. 2004), affecting the interpretation and the usefulness of the results. This study aimed to evaluate the use of a real-time polymerase chain reaction (PCR) assay based on a repeat element for the detection of $T$. gondii in brain and heart samples from free-range chickens seropositive for the parasite.

Blood samples from 65 free-range chickens from five farms located in Toledo, state of Paraná (PR), Brazil, were collected by wing vein puncture. Serum obtained by cen-

Financial support: Universidade Paranaense, Laboratório Álvaro/ Centro de Análises e Pesquisas Clínicas, Fundação Araucária de Apoio Científico e Tecnológico do Paraná

+ Corresponding author: aristeuvsilva@gmail.com

Received 3 May 2010

Accepted 20 July 2010 trifugation was analyzed using the modified agglutination test (MAT) using formalin-fixed RH strain tachyzoites as antigen, with an initial dilution equal to 1:25. Reactive serum samples were titered by successive two-fold dilutions to 1:3.200 (Desmonts \& Remington 1980).

MAT reactor birds were killed by cervical dislocation and their hearts and brains were collected. These samples were placed in $30 \mathrm{~mL}$ Falcon tubes containing an antibiotic solution (penicillin G + streptomycin) and were refrigerated until they were digested in a pepsin solution, as per Dubey et al. (2002), in the Preventive Veterinary Medicine and Public Health Laboratory at the Paranaense University, Umuarama, PR, Brazil. Following centrifugation, the pellet was weighed and resuspended in five times its volume of $0.9 \%$ saline solution to obtain a $200 \mu \mathrm{g} / \mathrm{mL}$ suspension. This suspension was immediately frozen at $-20^{\circ} \mathrm{C}$ for DNA extraction and molecular detection of $T$. gondii in the Molecular Biology Unit at the Álvaro Clinical Analysis and Research Center, in Cascavel, PR.

DNA was extracted from $400 \mu \mathrm{L}$ of the tissue suspension using Trizol ${ }^{\mathbb{R}}$ LS (Invitrogen, Paisley, UK) according to the instructions of the manufacturer. SYBR ${ }^{\circledR}$ Green was used to detect fluorescence in real-time PCR using the StepOne ${ }^{\mathrm{TM}}$ Real-Time PCR System (Applied Biosystems). The primer used (Invitrogen) amplified a $529 \mathrm{bp}$ region that is repeated 200-300 times in the genome of the parasite. The forward and reverse sequences were 5'CACAGAAGGGACAGAAGT3' and 5'TCGCCTTCATCTACAGTC3', respectively (Edvinsson et al. 2006). For the assay, each reaction mix had a final volume of $20 \mu \mathrm{L}$ and contained $10 \mu \mathrm{L}$ of SYBR Green PCR Master Mix (Applied Biosystems), $1.5 \mu \mathrm{L}$ of each primer at a concentration of $10 \mathrm{pmol} / \mu \mathrm{L}, 5 \mu \mathrm{L}$ of DNA and $2 \mu \mathrm{L}$ of sterile distilled water. The reaction was carried out as follows: 5 -min hot start at $95^{\circ} \mathrm{C}, 35$ cycles at $95^{\circ} \mathrm{C}$ for $30 \mathrm{~s}$, $55^{\circ} \mathrm{C}$ for $30 \mathrm{~s}$ and $72^{\circ} \mathrm{C}$ for $1.5 \mathrm{~min}$, followed by a final extension for $7 \mathrm{~min}$ at $72^{\circ} \mathrm{C}$. 
The number of parasites per gram of tissue was obtained by the formula (NF x 1000)/80, where the normalization factor (NF) was as follows: (DNA concentration in the standard curve/DNA concentration in the sample) $x$ number of amplicons in the sample. Samples that showed amplification signals lower than the minimum detection threshold of the standard curve underwent a second assay with 40 cycles, followed by melting curve analysis to check for the presence of primer dimers or other non-specific PCR products.

The DNA amplification frequency by tissue type was compared using McNemar's test, whereas DNA quantification in the different tissues was compared by the Wilcoxon test. Values were considered to be significant when $\mathrm{p}<0.05$.

The research protocol was submitted and approved by the Paranaense University's Committee on Ethics in Research Involving Animal Experimentation.

From the 65 serum samples tested, 28 (43.1\%) were positive in the MAT and the titres are shown in Table. The brains and hearts of 26 MAT-positive birds were collected for DNA extraction and amplification using realtime PCR. Two seropositive samples were not available for purchase and subsequent collection of tissue samples.

T. gondii DNA was amplified in $22(84.6 \%)$ of the 26 brain tissue samples tested in the quantification assay. Amplifications in five of these samples were lower than the minimum detection threshold of the standard curve and these results were confirmed in a second assay with 40 cycles followed by melting curve analysis. From the 26 heart samples evaluated, $21(80.8 \%)$ were positive for parasite DNA; six of these samples were confirmed positive in the second assay. No significant differences were observed between tissue types in the rate of positive samples $(p=0.6547)$ or in the quantity of DNA per gram of sample $(p=0.4258)$. Considering the results obtained in the brain and heart tissue samples, $T$. gondii DNA was amplified in $24(92.3 \%)$ of the birds analyzed. No statistical difference was observed $(\mathrm{p}=0.6547)$ in the detection of $T$. gondii in the tissues analyzed, confirming the evidence that cysts can frequently be found concomitantly in the heart and the brain, organs that are preferred locations for the cysts of this species (Dubey et al. 1993).

In the brain tissue samples, parasite detection ranged from 81-22,742 parasites per gram of tissue, with a median equal to 437 parasites per gram. In the heart tissue samples, detection ranged from 23-982 parasites per gram of tissue, with a median equal to 155 parasites per gram.

T. gondii DNA was not amplified in two samples with MAT titres equal to 800 . However, the cysts may not necessarily be located only in the tissues analyzed and it is possible that the DNA degraded during digestion.

The high sensitivity observed using this method and the region of the genome used corresponded with the sensitivity described by Jauregui et al. (2001) and Edvinsson et al. (2006), as demonstrated by the detection of one parasite per $\mathrm{mL}$ in both brain and heart tissue samples.

Jauregui et al. (2001) demonstrated that the difficulty of detecting $T$. gondii in the tissues of large animals was due to sampling bias, preferred parasite sites and the
TABLE

Farms, animals, respective antibody titer in modified agglutination test (MAT) and quantification of Toxoplasma gondii in samples of brain and heart of outbreed chicken in Toledo, Paraná, Brazil, 2008

\begin{tabular}{|c|c|c|c|c|}
\hline \multirow[b]{2}{*}{ Farm } & \multirow[b]{2}{*}{ Animal } & \multirow[b]{2}{*}{ MAT titer } & \multicolumn{2}{|c|}{$\begin{array}{l}\text { T. gondii quantity } \\
\text { (parasites/g) }\end{array}$} \\
\hline & & & Brain & Heart \\
\hline 1 & 7 & $\geq 3200$ & 672.06 & ND \\
\hline 1 & 10 & 50 & 114.55 & 118.58 \\
\hline 1 & 11 & $\geq 3200$ & ND & ND \\
\hline 1 & 15 & 800 & ND & 49.26 \\
\hline 1 & 17 & 800 & 486.70 & ND \\
\hline 1 & 18 & 200 & 109.67 & 155.21 \\
\hline 1 & 19 & 800 & ND & 58.07 \\
\hline 2 & 3 & 400 & ND & 571.76 \\
\hline 2 & 4 & 200 & ND & 33.49 \\
\hline 2 & 8 & 1600 & 234.02 & ND \\
\hline 2 & 9 & 400 & 228.23 & 982.80 \\
\hline 2 & 10 & 1600 & ND & 332.98 \\
\hline 2 & 13 & 800 & 263.31 & 23.68 \\
\hline 2 & 16 & 800 & 93.02 & 323.96 \\
\hline 2 & 17 & 400 & 435.20 & 831.65 \\
\hline 2 & 18 & 400 & 437.46 & 578.82 \\
\hline 2 & 19 & 1600 & 1470.09 & ND \\
\hline 3 & 1 & 800 & ND & ND \\
\hline 3 & 2 & 1600 & 22742.38 & 62.81 \\
\hline 4 & 5 & 200 & 518.93 & ND \\
\hline 4 & 8 & 1600 & ND & 60.06 \\
\hline 4 & 9 & 800 & 500.08 & ND \\
\hline 5 & 1 & 400 & 1350.80 & ND \\
\hline 5 & 2 & 800 & ND & ND \\
\hline 5 & 3 & $\geq 3200$ & 6545.50 & ND \\
\hline 5 & 9 & 400 & 81.10 & 163.75 \\
\hline
\end{tabular}

MAT titer: anti-T. gondii antibody titer in modified agglutination test; ND: not detectable.

possibility that, when performing any test for tissue cyst detection, false-negative results may occur due to insufficient sample size. These difficulties and the possibility of false-negatives are reduced with chickens because whole organs can be analyzed, including brains and hearts.

The results obtained in this study confirmed the analytical sensitivity of parasite detection in tissue samples from birds when amplifying a repeat element in real-time PCR using SYBR ${ }^{\circledR}$ Green fluorescent detection. Quantification of the parasite in these tissues demonstrated the possibility of applying other molecular detection systems for genotypic analysis directly to tissue samples. The results obtained using mouse inoculation could be compared with molecular detection systems, which may replace bioassays in the future. 


\section{ACKNOWLEDGEMENTS}

To Cintia Larissa Schmitt and Marciano Antunes, from the Álvaro Clinical Analysis and Research Center, for their technical help, to Ronaldo César da Rosa and Rodrigo Mattei (PIBIC/UNIPAR), Jacqueline Batista de Araújo and Franciele Rossandra Piassa (Master's degree course in Animal Science), for helping in the collection and preparation of the samples, and to Rodrigo Costa da Silva and Vanessa Yuri de Lima, from Zootechnical and Veterinary Medicine College at UNESP, for helping with the references.

\section{REFERENCES}

Desmonts G, Remington JS 1980. Direct agglutination test for diagnosis of Toxoplasma infection: method for increasing sensitivity and specificity. J Clin Microbiol 11: 562-568.

Dubey JP, Gennari SM, Labruna MB, Camargo LM, Vianna MC, Marcet PL, Lehmann T 2006. Characterization of Toxoplasma gondii isolates in free-range chickens from Amazon, Brazil. J Parasitol 92: 36-40.

Dubey JP, Graham DH, Blackston CR, Lehmann T, Gennari SM, Ragozo AM, Nishi SM, Shen SK, Kwok OC, Hill DE, Thulliez
P 2002. Biological and genetic characterisation of Toxoplasma gondii isolates from chickens (Gallus domesticus) from São Paulo, Brazil: unexpected findings. Int J Parasitol 32: 99-105.

Dubey JP, Ruff MD, Camargo ME, Shen SK, Wilkins GL, Kwok OC, Thulliez P 1993. Serologic and parasitologic responses of domestic chickens after oral inoculation with Toxoplasma gondii oocysts. Am J Vet Res 54: 1668-1672.

Edvinsson B, Lappalainen M, Evengård B 2006. Real-time PCR targeting a 529-bp repeat element for diagnosis of toxoplasmosis. Clin Microbiol Infect 12: 131-136.

Jauregui LH, Higgins J, Zarlenga D, Dubey JP, Lunney JK 2001. Development of a real-time PCR assay for detection of Toxoplasma gondii in pig and mouse tissues. J Clin Microbiol 39: 2065-2071.

Reischl U, Bretagne S, Krüger D, Ernault P, Costa JM 2003. Comparison of two DNA targets for the diagnosis of toxoplasmosis by real-time PCR using fluorescence resonance energy transfer hybridization probes. BMC Infect Dis 3: 7 .

Villena I, Marle M, Dardé ML, Pinon JM, Aubert D 2004. Toxoplasma strain type and human disease: risk of bias during parasite isolation? Trends Parasitol 20: 160-162. 